\title{
CULTURAL NARRATIVES OF THE LEGAL PROFESSION: LAW SCHOOL, SCAMBLOGS, HOPELESSNESS, AND THE RULE OF LAW
}

\author{
Daniel D. Barnhizer
}

2012 MiCH. ST. L. REV. 663

TABLE OF CONTENTS

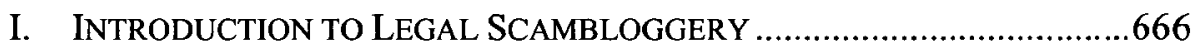

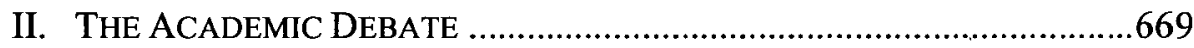

III. A LOOK AT THE SCAMBLOG COUNTERCULTURE.................................676

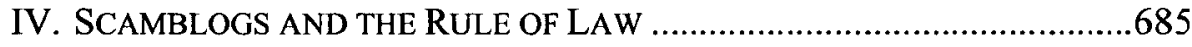

\section{INTRODUCTION}

Legal education is in crisis. Law schools cost more and deliver less in terms of career promise for their graduates than ever before. Where law students of two decades ago-now supposedly at the height of their professional careers - entered law school with at least some trepidation about how to repay the substantial financial cost of that education, those students still anticipated being able to follow in their fathers' or mothers' footsteps to fight for justice while earning a decent living. We expected a nice house or a decent apartment, a car, and the enjoyment of membership in a respected, even vaguely aristocratic profession.

We were steeped in the popular culture of the law, including the stories of L.A. Law, Ally McBeal, Matlock, and the many incarnations of Law \& Order. Our parents - both literal and metaphorical-had their own stories of lawyer as hero. Atticus Finch, Thurgood Marshall, the model of crusading civil rights lawyers in the trenches. These were larger-than-life people to look up to. These were stories we could tell ourselves about our profession

* Professor and Bradford Stone Faculty Scholar, Michigan State University College of Law. The Author cannot sufficiently express his appreciation for the insights, observations, analyses, and contributions to this September 8-9, 2011 "Lawyers As Conservators" symposium. All of you are part of the solution to the deep and critical problems facing our profession today. It has been a pleasure working with you. The Author also needs to thank specifically Professor Brian Z. Tamanaha, Professor Frank Snyder, Professor (Emeritus) David Barnhizer, Associate Dean Charles Ten Brink, Assistant Professor Dan Katz, and my research assistant, Elizabeth Palmer, for reading, reviewing, or commenting on earlier drafts of this Article. Finally, the Author extends appreciation to Dean Joan Howarth for her efforts toward addressing the problems facing our students and graduates as they face the harsh and threatening employment environment that now seems to define the legal profession. 
and our identities within that profession. The law was a profession worth belonging to.

While there have always been economic and financial pressures around the margins of law, law practice, and law school, these marginalia are becoming the new text. Approximately half of all students attending law school today will not get jobs requiring a J.D.' Even a large percentage of those with law jobs will be underemployed, and a startling number will not see a meaningful return on the approximately $\$ 150,000$ investment in their legal education. ${ }^{2}$ Law school debt has skyrocketed, and many recipients will live poverty-level lives while struggling to cover their debt service obligations. Others will descend into a hopeless spiral of nondischargeable student loans, wrecked credit scores, and miserable low-end jobs.

In response to this new narrative of what it means to be a law student and a newly minted J.D., a community of bloggers has crystallized a new culture-the legal "scamblog." Since at least 2010, the scamblog culture has been building a new mythical story for law schools and lawyers that identifies, explains, and legitimates a cultural expression for its members and a host of disenchanted lawyers. The scambloggers have their own language,

1. See, e.g., Matt Leichter, Law Graduate Overproduction, THE LAW SCHOOL TuITION BUBBLE, http://lawschooltuitionbubble.wordpress.com/original-research-updated/ law-graduate-overproduction/ (last visited Apr. 16, 2012). Leichter's detailed research on state government job creation projections for jobs requiring J.D.'s and Federal Bureau of Labor Statistics projections for legal jobs likely to be created between 2008 and 2018 shows that while law schools are on track to produce approximately 440,000 new law graduates in that ten year period, the U.S. economy overall will only produce approximately 200,000 new legal jobs during that time. See id.

2. The $\$ 150,000$ investment is a conservative number. Excluding scholarship recipients (I still believe law school can be a good deal if you get it for free), a paying law student will spend somewhere between about $\$ 18,500$ for resident in-state tuition at a public law school at the low end and over $\$ 50,000$ per year at the high end of private institutions. See BRIAN Z. TAMANAHA, FAILING LAW SCHOOLS 107-110 (2012) (discussing radical increases in law school costs, with many schools charging between $\$ 40,000$ and $\$ 50,000$ in tuition alone). Tuition is only part of the story. Students must eat, and while urban camping has its appeal, shelter is seen by many as a necessity. The law school costs calculator at AdmissionsDean.com shows that attending school in even relatively low cost-of-living cities like Cleveland, Ohio requires almost $\$ 19,000$ per year of living expenses, yielding a three-year total of $\$ 115,000$ for attending a low-cost public school like Cleveland State University, Cleveland Marshall College of Law. See Law School Cost Calculator, ADMISSIONSDEAN.COM, http:llwww.admissionsdean.com/paying_for_law_school/law-school -cost-calculator (last visited Apr. 16, 2012). Take the institution private or pay non-resident tuition and tuition costs increase significantly. Those numbers also fail to capture interest payments on the debt to finance the education-raising the cost an additional $\$ 40,000$ or more in interest on a $6.8 \%$ loan repaid over just ten years. Finally, a third major component of the cost of attending law school that most ignore is the lost opportunity to be earning wages, seniority, marketable skills, and experience in an alternative endeavor such as gainful employment or higher growth fields like plumbing or emu farming. Add this in, and even the cheapest law school can impose costs on paying students well in excess of $\$ 150,000$. 
their shared rejection of traditional taboos, and their own cosmological and xtiological explanations for the state of their world. These scambloggers and the community that coalesces around them may represent a serious threat not only to law schools but also, far more importantly, to the integrity of the Rule of Law.

This Article ${ }^{3}$ presents my thoughts and impressions drawn from extensive examination of the new counterculture of the law school scamblogs. It is intentionally informal in style, and the irony of attempting to capture this highly dynamic, information-era phenomenon in the print medium has not escaped me. ${ }^{4}$ Moreover, this Article does not catalog the factual background of job and debt statistics facing our graduates. Rather, I am attempting to present a feel, an impression, of the world many of our students and graduates perceive themselves to occupy. ${ }^{5}$ To that effect, I present these scamblog impressions in relation to their impact not just in their patent mission of preventing naïve or Pollyannaish applicants from attending law school (or at least from attending certain law schools), ${ }^{6}$ but in their latent mission of discrediting and undermining legal education, the practice of law, and the institutions of law itself.

Part I of this Article looks briefly at the narratives that define what it means to be a lawyer and how the revolutionary narratives of the scambloggers may threaten the system on which legal practice and education is currently based. In Part II, I address the academic and institutional side of the

3. I actually consider this to be an informal Essay, not an Article. This breach of law review conventions, however, has given my editor a nervous tic, and I bow to convention.

4. The major difficulty here is that no one knows whether the scambloggers will still be active by the time this Article sees print. My intuition is that they will be around in another form, and that even if scambloggers like Nando, Rose Colored Glasses, Rockstar05, BL1Y, and the others head off to greener pastures (good luck in that, for what it is worth), the themes and perceptions that they express will still be driving the identity of the underemployed and unemployed law graduate community for years to come.

5. Nor has it escaped me that I am one of the generic targets of the scambloggers' vitriol: a tenured law professor with the cushiest of jobs attempting from my comfortable corner office to write a gritty social justice essay that will be read by no one except my interested peers. Indeed, with circulation of a draft of this Article on SSRN, I have become a specific target of at least one scamblogger. See Demosthenes of America, Here's Why Law Professors Are Evil \& Generation Fantasy Camp, Outside Lies MaGiC: A LAw SCHOOL VENDETTA (Feb. 28, 2012), http://outsideliesmagic.blogspot.com/2012/02/heres-why-lawprofessors-are-evil.html. But I am not writing to the scambloggers--I am writing to my many peers who are deeply surprised when I provide anthropological snippets and snapshots of the developing subculture from our disenchanted and disenfranchised graduates.

6. See, e.g., Thomas M. Cooley law School SCam--Would YOU ATtend A LAW SCHOOL WITH A \$250 MILLION \$ Class ACTION LAWSUIT AGaINST IT?, http://thomascooley-law-school-scam.weebly.com/index.html (last visited Apr. 16, 2012) (critiquing the value of Thomas M. Cooley Law School and arguing that the school is a terrible investment for law students and graduates). 
debate over the state of legal education and the practice of law. Most of this can be described as hand wringing and deck chair rearranging, although the most honest and insightful of those who have engaged seriously with this issue agree that the current state of legal education is unsustainable. Part III examines the emerging counterculture of the scamblogs and attempts to identify community-defining memes within that counterculture. Finally, in Part IV, I consider the potential threats to legal education, legal institutions, and the Rule of Law generally that will arise from continued failure to address the problems generating the scamblogging counterculture.

\section{INTRODUCTION TO LEGAL SCAMBLOGGERY}

This Article examines the stories law faculty tell our students and ourselves about what it means to be a lawyer. The identity of the legal profession has been formed in part by the myths that we tell law students (and that more senior lawyers tell their mentees) about what it means to be engaged in the practice of law.

We tell war stories about our time in practice. ${ }^{7}$ am guilty of forcing students to listen to my laments about work hours, my sheer, total professional awesomeness in one of the few big law firm cases I handled solo from start to finish, and how, in some cases, it makes sense to pay more in settlement than the opponent could potentially receive at trial. We tell the myths and legends of heroes of the law that energized our own visions. My impression of Constitutional Law, for instance, was that the entire subject was nothing more than an endless hagiography of progressive justices who fit the liberal political framework of my professors.

We tell horror stories and morality tales that generally include lines like, "and then, kids, the big, bad unethical attorney said . ..." And we tell stories about the students themselves, including stories involving both loathsome behavior, such as plagiarism or lying about not smoking weed on the bar application, along with stories about great students and the professors who made them that way. We are "story tellers," and these stories generate the mythos and culture of an important part of the legal profession.

Although tongue in cheek, the above list of narrative types that we give to our students forms our culture and communicates to students the mythology of what it means to be a lawyer. This point is not groundbreaking-other scholars in the critical and narrative fields have observed that the legal community, like other communities, is defined by its stories and

7. However short that practice may have been, it is always good for a war story Even if we cannot think of a good one personally, we can draw on the stories with which friends, colleagues, luncheon speakers, and so on have regaled us over the years. 
myths. Mythical narratives ${ }^{8}$ identify and define membership within a group, justify and explain the existence and purpose of the group, and perpetuate the group's identity as new members enter and old members leave.

Dominant myths of the current legal culture are highly legitimating and enthrone the lawyer in place as a pillar of western civilization and protector of the rule of law. In our increasingly deluded mythology, we are vaguely aristocratic, ${ }^{9}$ valued members of society, bound by strong ethical codes, and part of an ethical profession that mediates between the machinery of the state and the needs of its citizens. We work hard, long hours. In the lexicon of Wile E. Coyote, we are super-geniuses.

Of course, the myths are not all good. The legal Valhalla would be incomplete without its Loki. Justice Taney makes a good villain. ${ }^{10}$ Similarly, Justices Scalia, Thomas, Roberts, and Alito seem to occupy a prominent place in some sort of Four Horsemen of the Progressive Apocalypse. Ambulance chasers, lawyers who write torture memos, and the attorneys who defend the Facebook "Privacy" Policy offer further examples of the "Dark Side" of the Force of the law. Along with this, attorneys who commingle client funds, have sex with their clients, provide poor service, or overbill clients all provide easy examples of the devils and demons of the legal profession. These serve a purpose as warnings and morality tales that remind the newest entrants to the profession that with great power comes great responsibility.

But as I will discuss below, the culture of our students and graduates may be shifting to a darker defining narrative. In this new mythic cosmology, the law student is an innocent child. Gullible and naïve, the matriculating law student was tricked into going to law school by a coterie of greedy deans and financial-cocaine dealing lenders; preyed upon by an uncaring, hypocritical, lazy, and disconnected faculty; and then when they have been bled dry, they are thrown out into the world to face a lifetime of debt slavery, hopelessness, and despair. Finally, when a few of them do manage to

8. I have adopted a broad definition of "myth" as a story that conveys a deeper meaning, regardless of its facticity. See DAvid BARNhIzER \& DANIEL D. BARNHIZER, HYPOCRISY \& MYTH: THE HIDDEN ORDER OF THE RULE OF LAW 201-03 (2009).

9. Thank you, Alexis de Tocqueville:

In America there are no nobles or literary men, and the people are apt to mistrust the wealthy; lawyers consequently form the highest political class and the most cultivated portion of society. They have therefore nothing to gain by innovation, which adds a conservative interest to their natural taste for public order. If I were asked where I place the American aristocracy, I should reply without hesitation that it is not among the rich, who are united by no common tie, but that it occupies the judicial bench and the bar.

Alexis de Tocqueville, Democracy in America 124 (Richard D. HeFFner ed., Penguin BOOKS 1956) (1835).

10. See Dred Scott v. Sandford, 60 U.S. 393 (1857) (opinion written by Chief Justice Taney). 
get their message out, they are derided as whining, irrational slackers by the president of the American Bar Association (ABA), ${ }^{11}$ informed that they are wrong and that there are plenty of jobs out there for them, ${ }^{12}$ or sued by their alma maters for defamation. ${ }^{13}$

This new narrative has the potential to define a majority of new lawyers. Not only does it better fit with and explain the harsh reality facing many new law graduates, but it also gives them a focus for their anger. In the new legal cosmology, law deans, law professors, the ABA, "Big Law," Sallie Mae, and other institutions of legal education, finance, and practice caused the lifetime of professional unemployment or underemployment to the point of debt slavery many of these individuals now face. In essence, we

11. In one of the most tone-deaf remarks I have witnessed in sixteen years of working in a profession for which tone-deafness is practically a job description, William Robinson III, President of the ABA, opined in a January 4, 2012 interview that:

"It's inconceivable to me that someone with a college education, or a graduatelevel education, would not know before deciding to go to law school that the economy has declined over the last several years and that the job market out there is not as opportune as it might have been for five, six, seven, eight years ago"....

David Ingram, ABA Head Has Little Sympathy for Jobless Lawyers, REUTERS.COM (Jan. 4, 2012), http://www.reuters.com/article/2012/01/05/us-usa-lawyers-jobless-idUSTRE80403K 20120105. In the same interview, Robinson opined that those who choose to go to law school can do so as "an independent decision and a free choice." Id. (further commenting that, "[w]e're not talking about kids who are making these decisions."). This is particularly ironic given that at the time he made these statements, only a handful of law schools across the country had responded to calls for greater transparency in post-employment reporting. Before this trickle of disclosures, every school reported employment according to an $\mathrm{ABA}$ and $\mathrm{Na}$ tional Association of Law Placement (NALP) formula that implicitly misrepresented and overstated the likelihood of graduate employment in a job following graduation. See, e.g., Larry Abramson, Do Law Schools Cook Their Employment Numbers?, NATIONAL PUBliC RADIO (Jan. 16, 2012), http://www.npr.org/2012/01/16/145179563/do-law-schools-cooktheir-employment-numbers (discussing recent lawsuits against various law schools for providing misleading job numbers and changes in ABA reporting requirements to require greater transparency). See also David Jesse, Law Firm: Cooley Law School Less Than Truthful About Job Stats, Detrort Free Press, Aug. 11, 2011, at A9 (describing class action claims by Kurzon Strauss law firm against Thomas M. Cooley Law School for allegedly publishing false or misleading employment statistics).

12. See Aaron N. Taylor, Why Law School Is Still Worth It, The National JURIST (Oct. 11, 2011), http://www.nationaljurist.com/content/why-law-school-still-worth-it. This Article, which as the title indicates, presents an optimistic view of why law students should ignore the gloomy predictions for the future legal job market, was needless to say poorly received by the scamblogging community. See, e.g., Paul Campos, Law Professor Solicits Fraud as a Recruitment Strategy, INSIDE THE LAW SCHOOL SCAM (Oct. 12, 2011), http://insidethelawschoolscam.blogspot.com/2011/10/law-professor-solicits-fraud-as.html; Nando, Profiles in Deliberate Misinformation and Blatant Dishonesty: Aaron Nathaniel Taylor, "Law Professor" at St. Louis University, THIRD TIER Reality (Oct. 12, 2011), http://thirdtierreality.blogspot.com/2011/10/profiles-in-deliberate-misinformation.html.

13. See David Jesse, Cooley Law School Sues over Online Criticism, DETROIT FreE Press, July 21, 2011, at A8 (describing defamation lawsuit by Cooley Law School against alum for criticizing Cooley in online blog). 
law faculty have become the "Other"-the enemy. As popular movements and revolutions throughout history have learned, nothing beats having a common enemy for creating and motivating a new group identity.

The divergence between the traditional narrative of lawyers as guardians of the Rule of Law and lawyers (and law professors who are the earliest role models) as demons who have tempted countless innocents into damnation represents a real threat to the integrity of the Rule of Law. The threat is not just to legal education..$^{14}$ Instead, the threat is to the institution of the Rule of Law itself as an emerging bitter generation of newly-minted attorneys identifies itself as the "tribe" that was betrayed and enslaved by bad faith at every level. That is the stuff of which revolutions are made.

\section{II.THE ACADEMIC DEBATE}

The academic side of the debate over what is wrong with law schools has been pretty muted until the last few years. Where we complain about things, it is further elaboration on literally a hundred years of debate over the best model for legal education. Law faculty and their administrations, increasingly spurred on by various interest groups, kvetch and moan about the state of legal education. The most common complaints have become that law schools are not producing "practice-ready" lawyers, how we need more experiential learning and practicum-type courses, and how we need to distinguish between "skills-based competencies" and "knowledge-based competencies." 15

The $\mathrm{McCrate}^{16}$ and the Carnegie ${ }^{17}$ Reports and numerous other critiques tell us we are not doing "it" right. In reality, despite all the Sturm und Drang, we make changes only at the margins. We scurry around shifting

14. Actually, legal education deserves to be threatened. The traditional legal educational model needs to feel the pressure and respond to the market realities facing our students. At the same time, the competing new models that demand smaller classes, more writing experience, more practicum, more clinics, more academic support, more staff, more faculty, and more administration drive prices skyward without any realistic market check. But see William D. Henderson \& Rachel M. Zahorsky, The Law School Bubble: How Long Will It Last If Law Grads Can't Pay Bills?, ABA JouRnal (Jan. 1, 2012), available at http://www.abajournal.com/magazine/article/the_law_school_bubble_how_long_will_it_last _if_law_grads_cant_pay_bills (suggesting that Congress will be forced to restrict government-backed student loans for law school because of increasing default rates and the Income Based Repayment program, in turn causing law school funding to dry up).

15. As edu-babble goes, these two really take the cake. I agree with my late friend and colleague, Professor Craig Callen, who often wondered what it was about some people that prevented them from simply using direct, simple terms like "skills" and "knowledge."

16. AMERICAN Bar AsSOC., SECTION OF Legal EdUCATION and Admissions to THE Bar, Task Force on law Schools and the Profession: Narrowing the Gap, Legal EdUCATION AND PROFESSIONAL DEVELOPMENT-AN EdUCATIONAL CONTINUUM (1992).

17. William M. Sullivan, AnNe Colby, Judith Welch Wegner, Lloyd Bond, Lee S. Shulman, Educating LaWyers: Preparation for the Profession of Law (2007). 
curricular deck chairs that are basically all of the same design and fabric, add clinics to service every progressive wish-list about perceived discrimination, increase remedial writing program requirements because many students are deficient in that regard, and add academic support personnel for counseling and tutoring because many of the students admitted to law school probably should not be allowed into the enterprise in the first place. ${ }^{18}$ But because we have admitted the otherwise inadmissible, and because law school finances are dependent on student tuition payments, we incur a high cost to "nurture" those who are neither particularly good students nor likely to become good lawyers no matter how many skills courses through which we put them. And law schools only get more and more expensive. ${ }^{19}$

There are a few voices that have been crying in the wilderness for years over the unsustainable law school education financial model. Brian Tamanaha, for instance, has blogged extensively on the subject. ${ }^{20}$ The elder

18. I would be remiss not to note the extraordinary administrative costs that appear to drive much of the increase in the cost of legal education. See, e.g., BENJAMIN GINSBERG, The Fall of the Faculty: THE Rise of the All-Administrative UNIVERSITY and Why IT MATTERS (2011).

19. See Matt Leichter, Tuition Increases at All ABA Law Schools (2005-), THE LAW SCHOOL TUITION BUBBLE, http://lawschooltuitionbubble.wordpress.com/original-researchupdated/the-1stb-data/ (last visited Apr. 16, 2012) (providing raw data on law school tuition rates at all ABA accredited law schools); see also Matt Leichter, Private Law School Tuition Projections, The LAw SCHOOL TuiTION BubBle, http://lawschooltuitionbubble.wordpress. com/original-research-updated/tuition-projections/ (last visited Apr. 16, 2012). Matt Leichter has collected data from all law school websites and the Law School Admissions Council and compiled information on tuition increases over the last five years. Id. Admittedly, a very small number of law schools have occasionally reduced their tuition rates in individual years, but the trend for all law schools is clearly an increase in the cost of legal education at rates well in excess of inflation. Id.; see also Brian Tamanaha, A Peculiar Fairness Issue Brewing in Law Schools, BALKINIZATION (May 11, 2006, 4:01 PM), http://balkin.blogspot.com/ 2006/05/peculiar-fairness-issue-brewing-in-law.html ("Tuition goes up every year in law schools around the country, generally in a range between $5 \%$ and $10 \%$; sometimes less, sometimes more, but rarely not at all."). The raw data for law school tuition rates is available from the Law School Admissions Council (LSAC). See Official Guide to ABA-Approved Law Schools Archives (2008-2011), LSAC, http://www.lsac.org/LSACResources/ Publications/official-guide-archives.asp (last visited Apr. 16, 2012); Official Guide to ABAApproved Law Schools Archives (2006-2007), LSAC, http://www.lsac.org/LSACResources/ Publications/official-guide-archives-2.asp (last visited Apr. 16, 2012).

20. Tamanaha is one of the most persistent, cogent, and historically prescient voices on this issue, raising the alarm on unsustainability as far back as 2006. See Tamanaha, supra note 19. Tamanaha's recent book, FAILING LAw SCHOOLs (see supra note 2) provides a compelling and damning critique of the various factors and interest groups that have contributed to the slow-motion disaster that is legal education. A partial list of Professor Tamanaha's extensive commentary in this field also includes, Brian Tamanaha, Are Law Schools Harming Individuals and Society?, BALKINIZATION (Nov. 29, 2007, 10:11 AM), http://balkin.blogspot.com/2007/11/are-law-schools-harming-individuals-and.html; Brian Tamanaha, A Slice of Information About Corporate Law Firms and Legal Academia, BALKINIZATION (Jan. 31, 2007, 3:25 PM), http://balkin.blogspot.com/2007/01/slice-of- 
Barnhizer (David, not his younger and wittier son, Daniel) raised his children on stories of what is wrong with legal education. ${ }^{21}$ Following the series of exposés in the New York Times in 2011, most of the legal academy is generally aware that there is, in fact, a serious problem with the sustainability of the current model of legal education. ${ }^{22}$ Of course, the fact that most law faculty are only now waking to the crisis is itself a judgment on those faculty who ignored the "writing on the wall" for well over a decade. Little wonder that the "scambloggers" have felt righteous anger at the game that has been played on them.

But even most of this tardy discussion has been merely decorous handwringing around the edges. In January of this year, for example, I broke my five-year-old vow never to attend another Association of Ameri-

information-about-corporate.html; Brian Tamanaha, What's Wrong with This Picture of Legal Academia?, BALKINIZATION (Jan. 22, 2008, 12:29 PM), http://balkin.blogspot. com/2008/01/whats-wrong-with-this-picture-of-legal_22.html; Brian Tamanaha, Is There an Impending Crisis in Non-Elite Law Schools?, BALKINIZATION (Jan. 18, 2008, 11:14 AM), http://balkin.blogspot.com/2008/01/is-there-impending-crisis-in-non-elite.html; Brian Tamanaha, Why the Interdisciplinary Movement in Legal Academia Might Be a Bad Idea (For Most Law Schools), BaLKINIZATION (Jan. 16, 2008, 9:44 AM), http://balkin. blogspot.com/2008/01/why-interdisciplinary-movement-in-legal.html; Brian Tamanaha, Wake Up, Fellow Law Professors, to the Casualties of Our Enterprise, Balkinization (June 13, 2010, 6:48 PM), http://balkin.blogspot.com/2010/06/wake-up-fellow-law-professors-to.html; Brian Tamanaha, An Unlikely Champion of Reform in Legal Academia-Dean Matasar, BALKINIZATION (Oct. 27, 2010, 5:07 PM), http://balkin.blogspot.com/2010/ 10/unlikelychampion-of-reform-in-legal.html; Brian Tamanaha, The Irresponsibility of Law Schools, BALKINIZATION (Oct. 18, 2010, 2:05 PM), http://balkin.blogspot.com/2010/10/ irresponsibility-of-law-schools.html; Brian Tamanaha, My "Dean's Vision" Speech, BalkinIZATION (Nov. 16, 2010, 11:43 AM), http:// balkin.blogspot.com/2010/11/my-deans-visionspeech.html; Brian Tamanaha, Why Law Schools Need External Scrutiny, BALKINIZATION (Oct. 7, 2011, 7:00 AM), http://balkin.blog spot.com/2011/10/why-law-schools-needexternal-scrutiny.html.

21. See, e.g., David Barnhizer, Redesigning the American Law School, $2010 \mathrm{MicH}$. ST. L. REv. 249, 250-51 (2010) ("[Q]uite a few law faculty members will find themselves with reduced incomes, restricted or non-existent tenure options, and higher teaching workloads. In many instances, tenure-track and even tenured law faculty in schools that are vulnerable to the emerging competitive alternatives will replicate the stunning experiences of millions of white-collar workers in America's industries, who thought they had good-paying life-long jobs, only to find themselves on the streets as their companies downsized or went out of business."); David Barnhizer, Truth or Consequences in Legal Scholarship?, 33 HOFSTRA L. REV. 1203, 1207-18 (2005) (noting the destructive potential of much of modern activist legal scholarship on the value of the overall academic mission of law schools); David Barnhizer, Freedom to Do What? Institutional Neutrality, Academic Freedom, and Academic Responsibility, 43 J. LEGAL EDUC. 346, 347 (1993) (critiquing value of much legal scholarship).

22. David Segal, Is Law School a Losing Game?, N.Y. TIMES, Jan. 9, 2011, at BU1 (suggesting that law school is a poorly-performing investment for many, if not most, law students); David Segal, Behind the Curve, N.Y. Times, May 1, 2011, at BU1; David Segal, Law School Economics: Ka-Ching!, N.Y. TIMES, July 17, 2011, at BU1; David Segal, What They Don't Teach Law Students: Lawyering, N.Y. TIMES, Nov. 20, 2011, at A1. 
can Law Schools (AALS) annual meeting conference. This meeting, however, was worse than I had remembered precisely because of context. Yes, a full day was devoted to panels regarding the fate of legal education and the legal profession in the new Obama economy. ${ }^{23}$ But in an era when we are ostensibly worried about our customers' pending lifetime of debt slavery, the event was vaguely reminiscent of the grand balls of Louis XVI and Marie Antoinette. ${ }^{24}$ According to AALS officials at this year's event, approximately 3,000 law faculty attended the event in Washington, D.C. Assuming an average guesstimate of somewhere between $\$ 1,500$ and $\$ 2,500$ to attend, those in attendance gladly chewed up the cumulative equivalent of 3,000 to 5,000 paying student credit hours so we could attend a handful of presentations in our subject matters and go to a four-day party in an expensive city. As for law schools' alumni and students, they can always eat cake.

What this year's annual meeting brought home to me in dramatic and powerful fashion is that the academy will never fix itself. We are too polite about the problem and too dysfunctional in terms of internal politics to challenge the status quo in any meaningful fashion. We are "collegial" to the $n$th degree, and if you break ranks, you are ostracized as "insensitive" if you dare do so from the podium of a first tier law school and ignored if teaching at an "also-ran" institution. The market will almost certainly take care of some of the problem in coming years but only at the cost of a hundred thousand or more ruined lives. ${ }^{25}$

It is worth noting that 2011 may be remembered as the year that legal academia abandoned the tea and crumpets mentality for a short while. ${ }^{26}$ Following David Segal's series of articles in the New York Times beginning in January $2011,{ }^{27}$ an anonymous blogger claiming to be a tenured faculty member at a top tier law school began a blog titled: Inside the Law School

23. I actively attended these meetings and thought that many of the presentations were excellent. So excellent that it justified moving 3,000 law professors to a single location for four days that happened to coincide with fine dining, great nightlife, the chance to test our wits against the mazelike corridors of the Wardman-Park Hotel, and some really good swag at the vendors' exhibition hall? No.

24. Indeed, the AALS annual meetings come complete with an expensive gala "ball." Many law schools magnify their costs significantly by sponsoring nightly catered receptions. At least the shrimp is good.

25. See, e.g., Henderson \& Zahorsky, supra note 14 ("Given the likelihood of some form of curb in federal student lending, there are gut-wrenching times ahead for law schools - even those that continue to enjoy a surplus of applicants.").

26. See Paul Campos, 2011: The Year the Bubble Began to Burst, INSIDE THE LAW SCHOOL SCAM (Dec. 31, 2011, 10:24 AM), http://insidethelawschoolscam.blogspot. com/2011/12/2011-year-bubble-began-to-burst.html ("I suspect that in retrospect 2011 will be remember as the year the law school bubble finally began to burst.").

27. See supra note 22 . 
Scam..$^{28}$ The inaugural August 7, 2011, post, Welcome to My Nightmare, included this damning evaluation of legal education:

It is this: I can no longer ignore that, for a very large proportion of my students,
law school has become something very much like a scam. And who or what is do-
ing the scamming? . . . [W] [hat, for legal academics at least, ought to be the most
particular, most important, and most morally and practically compelling level, the
scammers are the $200 \mathrm{ABA}$-accredited law schools. Yet there is no such thing as a
"law school" that scams its students-law schools are abstract social institutions,
not concrete moral agents. When people say "law school is a scam," what that real-
ly means, at the level of actual moral responsibility, is that law professors are
scamming their students.

The anonymous blogger-who later revealed himself as Paul Campos, a tenured faculty member at the University of Colorado Law Schoolgenerated a significant response in the academic community and was widely discussed by news sites and other academic blogs. Notably, Campos's claims apparently tapped into a simmering uneasiness in the legal academy about the difficulties faced by many of our graduates following graduation. While this uneasiness had previously manifested in the form of Cassandralike warnings ${ }^{30}$ and "what can we do about it"-style essays, Campos's direct charge that law professors themselves were engaged in "scamming" students changed the nature, if not the quality, of the debate.

For example, Brian Leiter, a regular commentator on all things involving the legal academy, and Michael Olivas, then-current president of the AALS, vociferously responded to Campos's critiques of the profession and attacked Campos's musings on a personal level. ${ }^{31}$ Leiter opined that Campos was grandstanding and being irresponsible:

ScamProf is the failed academic who has done almost no scholarly work in the last decade, teaches the same courses and seminars year in and year out, and spends his time trying to attract public attention, sometimes under his own name, this time anonymously. These are important facts about ScamProf, since he is indeed scam-

28. See Paul Campos, INSIDE THE $\underset{\text { LAW }}{\text { SCHOOL }}$ SCAM,
http://insidethelawschoolscam.blogspot.com (last visited May 15, 2012).
29. Paul Campos, Welcome to My Nightmare, InsIDE THE LAW SCHOOL SCAM (Aug. 7, 2011, 6:40 AM), http://insidethelawschoolscam.blogspot.com/2011/08/welcome-to-mynightmare.html (emphasis in original).

30. Again, I have to convey my respect here for Brian Tamanaha's long-term struggle to raise awareness of the deep-rooted problems facing traditional models of legal education. See supra note 20.

31. Brian Leiter, Isn't It Obvious Who the "LawProf" Writing the Latest "Law School Scam" Blog Is?, BRIAN LEITER'S LAW SCHOOL REPORTS (Aug. 12, 2011), http://leiterlawschool.typepad.com/leiter/2011/08/isnt-it-obvious-who-the-lawprof-writingthe-latest-law-school-scam-blog-is.html. Leiter's initial response implicitly suggested that Campos had been irresponsible in his charges: "More seriously, when [Campos's] identity becomes public, as seems inevitable given how poorly he has disguised it, he will have humiliated his colleagues and his school, neither of which deserve his latest exercise in seeking the limelight." Id. 
ming his students and his state, and his initial posts were tantamount to a confession that he's not doing his job. His colleagues, in any case, now know who he is, and are quite understandably angry, since the reckless genearlizations [sic] are naturally read as commentary on them. ${ }^{32}$

Similarly, Olivas suggested that Campos's accusations were "unfair and inaccurate" and that Campos should return his salary if he felt that he had scammed his students. ${ }^{33}$ Other legal bloggers, including Larry Ribstein and Paul Horwitz, provided additional reasoned critiques of Campos's work..$^{34}$

This discussion was remarkable because while Campos was echoing the bitterness and anger of some law school scamblogs maintained by disgruntled and unemployed or underemployed law graduates, the academic debate quickly turned it into the boring and genteel discussion that we often use to defuse personal feelings over hotly debated topics. Campos called law faculty scammers and provided over the next several months a focal point for law school scambloggers across the internet. ${ }^{35}$ While some, such as Olivas and Leiter, denied most of his factual claims and others, such as Ribstein and Horwitz, challenged the arguments on scholarly grounds, the discussion overall carried an air of a duel between gentlemen and gentlewomen at dawn.

That is the culture we live in as legal academics. There is the occasional knife-in-the-back comment at faculty meetings or behind closed doors. This is accompanied by paeans to civility and collegiality as well as sensitivity and reasoned discussion that, for roughly one hundred years, has resulted in no meaningful change to the legal academy outside of marginal and highly-expensive developments such as clinical programs, legal writing, reshuffling of basic curricula, and calls for more practical experience in the classroom and practical relevance in scholarship. ${ }^{36}$

32. Brian Leiter, Update on ScamProf, BRIAN LeITER's LAW SCHOOL REPORTS (Aug. 19, 2011), http://leiterlawschool.typepad.com/leiter/2011/08/update-on-scamprof.html\#tp.

33. Scott Jaschik, Hostile Witness, INSIDE Higher ED, (Aug. 9, 2011, 3:00 AM), http://www.insidehighered.com/news/2011/08/09/tenured_law_professor_aims_to_expose_t he_excesses_of_his_profession.

34. See Larry Ribstein, A Response to LawProf and MacEwen, TRUTH ON THE MARKET (Aug. 19, 2011), http://truthonthemarket.com/2011/08/19/a-response-to-lawprofand-macewen/; Paul Horwitz, I Am LawProf, PrawfsBlawg (Aug. 11, 2011), http://prawfsblawg.blogs.com/prawfsblawg/2011/08/i-am-lawprof.html; Paul Horwitz, No Longer Anonymous, But Still Not Quite Right, PrawfSBlawg, (Aug. 21, 2011), http://prawfsblawg.blogs.com/prawfsblawg/2011/08/no-longer-anonymous-but-still-notquite-right.html.

35. See Campos, supra note 29.

36. Some of these programmatic changes definitely have value. But they are expensive in terms of personnel, time, and money. Experiential learning requires a dramatically lower instructor-student ratio than traditional doctrinal classes. Likewise, writing and legal methods classes require intensive interaction throughout the semester between the instructor and the students, meaning that the instructor can only teach a small number of students at a 
We do not trash our colleagues (in the open) because it is just not done. We do not call new programs, classes, buildings, clinics, faculty, administrators, and so on "expensive boondoggles and abject failures" to their faces because it just is not done. It is usually sufficient to use culturally acceptable phrases like "insufficiently nuanced," "overconcentration of faculty or programs," "administrative bloat," and so on.

These phrases are useful in the sense that they still let us talk to each other at faculty picnics and because the law faculty culture is such that "insufficiently nuanced" when applied to a colleague's scholarship is understood by everyone in the room to mean something like "this person is a lousy scholar and couldn't write his way out of a wet paper bag." Similarly, "administrative bloat" is the code phrase for "we hired another Assistant Associate Dean of Student Development and Community Good Feelings? Really?" The lexicon and thesaurus of legal academic "edu-babble" are full of such legerdemain that deflect real debate while not creating a factual record or admission that outsiders could use against us.

Unfortunately, such codes and private languages tend to cover up deep problems in much the same way that some United Nations bureaucrats apparently still believe that depraved dictators fear a strongly-worded diplomatic resolution. The code grows to consume and cover real issues until the system producing that language is revealed as entirely out of touch or hypocritical. ${ }^{37}$

Part of the problem-a major part-is that we are trapped within an orthodoxy that is largely closed off from the events of the world. This means we deceive ourselves because we are making decisions based on the data allowed into the system, and much of that information is blocked, diluted, or reinterpreted to fit our preconceptions. The distinction between how we perceive the threats faced by our graduates versus the realities of their boots on the ground impairs our ability to perceive the problem in the first instance or understand its real nature and consequences before it is too late to take effective corrective action.

As part of this collective delusion, we continue to use code phrases such as: "Legal job applicants do have a harder time now, but with patience and hard work, the jobs are out there," "A law degree is useful for opening

time. While such changes to the traditional curriculum and educational model likely improve either learning outcomes or student perceptions about their educational experience, they also increase the cost of that education.

37. See, e.g., Roscoe Pound, Law in Books and Law in Action, 44 AM. L. Rev. 12, 15 (1910) ("But if we look closely, distinctions between law in the books and law in action, between the rules that purport to govern the relations of man and man and those that in fact govern them, will appear, and it will be found that today also the distinction between legal theory and judicial administration is often a very real and very deep one."). 
many career opportunities besides practicing law, ${ }^{, 38}$ and so on. In the face of the stark and harsh realities facing our graduates, however, these are not mere platitudes. They are twists of the knife that emphasize just how clueless we law faculty actually are.

\section{A LOOK AT THE SCAMBLOG COUNTERCULTURE}

The emergent cultural narrative of the "law school scamblogs" suggests that the legal academy is already out of touch with the realities faced by the roughly 20,000 to 25,000 law graduates each year for whom there will likely never be a job requiring their newly minted J.D.'s. ${ }^{39}$ These weblogs are written by current students, former students, recent graduates, practicing lawyers, and (with Campos's contribution) law professors.

The scamblogs are defined by a single, basic premise: law school is a scam on the order of a true fraud that produces a lifetime of debt slavery in its victims. Beyond this basic premise runs a range of opinions and analyses from the proposition that current legal education models cannot withstand rational scrutiny to the substantially more violent and bitter suggestions that members of the legal elite should be liquidated. ${ }^{40} \mathrm{I}$ firmly believe that most law professors and administrators have no idea of the actual degree of bitterness and loathing held against us and our profession by this emerging culture of disenfranchised law graduates and impoverished students.

The names of the blogs themselves communicate something of the anger, hate, and despair felt by the scambloggers: Tales of a Fourth Tier Nothing, ${ }^{41}$ Law School Must Be Debunked, ${ }^{42}$ Super-Duper: The Non-Traditional Law Student Confidence Game, ${ }^{43}$ The PresTTTigious Legal Profession: A Blog About This Country's Most Miserable "Profession," Law, ${ }^{44}$ Life's Mockery, ${ }^{45}$ Fluster Cucked, ${ }^{46}$ Scammed Hard! ${ }^{47}$ Rose Colored Glasses, ${ }^{48}$

38. For an excellent example of this Pollyannish attitude toward the legal job market, law school debt, and lawyer incomes, see generally Taylor, supra note 12. As Taylor opines at the end of the article, "Don't believe the hype. Law school is still worth it." Id.

39. See Leichter, supra note 1.

40. See infra notes 80-86.

41. TAles of a FOURTH Tier NOTHING, http://poetryforpants.blogspot.com/ (last visited Apr. 16, 2012).

42. LAW SCHOOL MUST BE DEBUNKED, http://lawschoolmustbedebunked.blogspot $. c o m /$ (last visited Apr. 16, 2012).

43. Super-Duper: The Non-Traditional Law Student Confidence Game, http://dupednontraditional.blogspot.com/ (last visited Apr. 16, 2012).

44. The PrestTTigious Legal Profession: A Blog About this Country's Most Miserable "Profession," Law, http://prestttigious.blogspot.com/ (last visited Apr. 16, 2012). 2012).

45. LIFE'S MOCKERY, http://lifesmockery.wordpress.com/ (last visited Apr. 16, 
Subprime JD ${ }^{49}$ The Jobless Juris Doctor, ${ }^{50}$ Third Tier Reality, ${ }^{51}$ Toiletlaw ${ }^{52}$ Children of Debt ${ }^{53}$ Sallie Mae's Bitch, ${ }^{54}$ and The Angry Future Expat. ${ }^{55}$ This partial list does not include the large number of blogs that are not directed exclusively at the scamblogging enterprise but that nonetheless rebroadcast and add occasional contributions to the theme. ${ }^{56}$

At one end of the scamblogging spectrum, there are several reasonable voices that have marshaled an incredible amount of data demonstrating that law school is an abysmally bad investment for many, if not most, students. They show that most law students will never find full employment in a field requiring a J.D. and that law school tuition and student debt are both on a collision course with unsustainable disaster. For example, as noted above, Matt Leichter's The Law School Tuition Bubble blog is admirably encyclopedic and factual with respect to gathering, assessing, digesting, and disseminating data relating to the crisis facing legal education. ${ }^{57}$ As Leichter himself notes, the purpose and tone of his blog is professional and reasoned: 2012).

46. FLUSTER CUCKED, http://flustercucked.blogspot.com/ (last visited Apr. 16, 2012).

47. SCAMMED HARD!, http://scammedhard.blogspot.com/ (last visited Apr. 16,

48. ROSE COLORED GLASSES, http://rosecoloredglassesjd.blogspot.com/ (last visited Apr.16, 2012).

49. SUBPRIME JD, http://subprimejd.blogspot.com/ (last visited Apr. 16, 2012).

50. See The Jobless Juris Doctor, ABA JouRNAL, http://www.abajournal.com/ blawg/the_jobless_juris_doctor/ (last visited Apr. 16, 2012) (original site no longer active). 2012).

51. THIRD TIER REALITY, http://thirdtierreality.blogspot.com/ (last visited Apr. 16,

52. TolletLAw, http://toiletlaw.com/ (last visited Apr. 16, 2012). 2012).

53. CHILDREN OF DEBT, http://childrenofdebt.blogspot.com/ (last visited Apr.16,

54. SALlie MAE's BITCH, http://almostdebtfree1.blogspot.com/ (last visited Apr. 16, 2012).

55. THE ANGRY FUTURE EXPAT, http://angryfutureexpat.wordpress.com/ (last visited Apr. 16, 2012).

56. For instance, the message board JD Underground serves as an information dump on legal opportunities, strategies for unemployed and underemployed lawyers, as well as general griping and insights into the challenges facing new lawyers. JD UNDERGROUND, http://www.jdunderground.com/all/ (last visited Apr.16, 2012). Such forums are clearly part of the developing scamblogging narrative, but they are not entirely focused on the "law school scam" as such.

57. Matt Leichter, THE LAw SchOOL TuITION BubBle, http://lawschooltuitionbubble.wordpress.com/ (last visited Apr.16, 2012). Leichter's digest is the one blog that convinced me of the seriousness of this crisis. While the vast majority of law school scambloggers come off at first blush as whiny slackers who failed in law school and in the job market, Leichter's work is stunning in detail, breadth, and insight. Legal educators and administrators owe him a debt for the work he has done in careful collection and analysis of the flaws underlying the financial models of legal education. And if the irony would not cause a spontaneous thermonuclear explosion, I would try to get him a job teaching law students critical analysis and reasoning. Every person involved in legal education 
The Law School Tuition Bubble is technically not a law school scamblog, but after a few months I found myself allied with them over many substantive issues. However, though my opinions and tone can be quite passionate and critical of individuals' work, the emotional source of this website is professional, not personal. ${ }^{58}$

Although there are a few other scamblogs on the reasonable end of the scale, Leichter clearly stands out as one of the most reasonable (in the sense of "please listen to my fully- and academically-supported arguments that legal education is following an unsustainable model and is causing extreme human hardships" reasonable), persuasive, and valuable voices in the law school scamblogging community.

The vast majority of the remaining legal scambloggers are developing a cultural mythology about what being a lawyer "really" means. In that dystopian narrative, being a lawyer means scrabbling for garbage jobs and temporary contract work for low pay while struggling to pay basic bills. It means that you were defrauded and cheated by fat cat, hypocritical, overpaid, greedy, parasitic law professors and deans. It means hopelessness and despair from a lifetime of indentured debt slavery (with an associated underground railroad meme suggesting that to escape you have to leave the country). And more often, being a lawyer means fighting back to destroy the system that screwed you over.

The universe of jobs available to the unsuccessful or undersuccessful legal job market candidates is displayed throughout the scamblogs, but several sites seem to make a hobby of documenting the misery. One site, Shit Law Jobs, literally serves as a clearinghouse for low-value trash jobs with crummy pay, bad hours, no benefits, and no future. ${ }^{59}$ Surfing even a few entries at random reveals gems like document reviewing jobs in New York City at $\$ 25-\$ 30$ per hour for a J.D. with experience in document review or $\$ 22$ per hour with no overtime for a J.D. with an engineering degree. ${ }^{60}$ Other exciting openings include the opportunity to work from home doing twenty to forty hours of research at $\$ 25$ per hour with the successful applicant in-

should be equipped with Clockwork Orange-style vision enhancers and forced to scroll through his work.

58. Matt Leichter, About, The Law SchoOl Tuition BubBle, http://lawschool tuitionbubble.wordpress.com/about/ (last visited Apr. 16, 2012).

59. See New York City Document Review Attorney Jobs, ShIT Law Jobs (Dec. 29, 2011), http://www.shitlawjobs.com/2011/12/new-york-city-document-review-attorney.html. As the blog notes on its About Us page:

Are you a laid-off lawyer or a recent law school graduate and desperate for a job? Perhaps we can help. We don't list jobs everyone wants. Instead, we list jobs most lawyers likely wouldn't want. But, hey, it beats being unemployed.

What is "shit law"? In short, it's a subset of lawyer jobs that are low-paying with long hours and often involve insipid work.

About Us, SHIT LAW JOBS, http://www.shitlawjobs.com/p/about-us.html (last visited Apr. 16, 2012).

60. See New York City Document Review Attorney Jobs, supra note 59. 
curring the obligation to draft their own contract and pay for their own Lexis or Westlaw time, ${ }^{61}$ a $\$ 10$ per hour contract attorney gig in Seattle, ${ }^{62}$ and an Allentown, Pennsylvania landlord who needs an attorney at $\$ 30$ per hour with "[j] ust a little experience required" "to help us prepare/review our documents and ... provide us some instructions on how [to] file various documents." ${ }^{63}$

The selection of jobs on sites like Shitlawjobs.com likely represents the bottom of the barrel in terms of legal job offerings ${ }^{64}$ chosen more for their dark humor value than for their representativeness of the spectrum of paid legal opportunities awaiting new graduates or the recently unemployed. ${ }^{65}$ But other members of the community do popularize the meme that these are the jobs for which law schools and academics have lured them to invest $\$ 150,000$ and three years of their lives.

For example, Temporary Attorney: The Sweatshop Edition, represents the "Shit Law Job" as the future of most new attorneys:

This is what it's come to, kids. "Down the road," as they say in the big house. Four years of college, the LSAT, 3 years of law school, the late nights studying until your eyes bleed, $100 \mathrm{~K}$ plus in loans, the bar'zam, the dues, the CLE shakedowns: all to beg for a graveyard shift gig at a whopping $\$ 30$ an hour, sans OT. Trying to pay down loans at this rate is akin to using a Folgers can to bail out the Titanic: you'll drown long before the bilge is emptied. ${ }^{66}$

61. See Work-From-Home Legal Research Job, SHIT LaW JoBS (Dec. 6, 2011), http://www.shitlawjobs.com/2011/12/work-from-home-legal-research-job.html ("Willing to pay through PAYPAL, upfront deposit as long as we have written contract, which I expect you to draw up. . . . You must have your own access to PACER, LEXIS, and possibly Westlaw. I will not be ... covering those expenses.").

62. See Entry-Level Contract Attorney Job in Seattle, SHIT LAW JobS (Nov. 8, 2011), http://www.shitlawjobs.com/2011/11/entry-level-contract-attorney-job-in.html.

63. See Legal Work for Allentown, PA Landlord, SHIT LAW JOBS (Oct. 24, 2011), http://www.shitlawjobs.com/2011/10/legal-work-for-allentown-pa-landlord.html.

64. As one attorney commented in response to a draft of this Article, these "Shit Law Jobs" are not, in fact, the bottom of the barrel for many lawyers. The real bottom of the barrel comprises the unpaid internships offered to law students and graduates, coupled with false promises by some employers that the unpaid internship could mature into a full-time position. This attorney never responded to my request to cite him, and given the context, I must maintain his anonymity. See also Paul Campos, Working for Free and Class Bias, INSIDE THE LAW SCHOOL SCAM (Jan. 16, 2012), http://insidethelawschoolscam. blogspot.com/2012/01/working-for-free-and-class-bias.html.

65. See id.

66. Helpme123, Graveyard of Dreams: De Novo's "Night Shift", TEMPORARY ATTORNEY: ThE SWEATSHOP EDITION (Mar. 16, 2011, 12:12 PM), http://temporaryattorney. blogspot.com/2011/03/graveyard-of-dreams-de-novos-night.html; see also A Terrified Law Student, My Internship from Hell!, EPIC FAIL: LAW SCHOOL DISASTER (Jan. 11, 2012, 8:36 AM), http://lawschoolfail.blogspot.com/2012/01/my-internship-from-hell.html (relating negative internship experience). 
Other writers build on an additional narrative that, far from the oft repeated claim that a law degree is a valuable asset that can open doors beyond the practice of law, the J.D. is actually a job-killing vampire that sucks the lifeblood out of the holders' resumes and makes them unemployable in any non-legal field. ${ }^{67}$ Think about it. What manager wants a mouthy, failed lawyer looking at everything he or she does? It either means trouble overseeing the person, a lawsuit if you try to get rid of the person, or someone who wants your job and maybe has higher academic credentials that could help them replace you. No one trusts a lawyer.

Other blogs concentrate on the hypocrisy of law school faculty and administrators. The author of Do As I Say, Not As I Do, for instance, is a former law student who dropped out after earning poor grades first semester. ${ }^{68}$ This blog is visceral in its loathing for what the author sees as the parasitic, fraudulent, and hypocritical actions of law faculty: "Law professors are the problem. Their obscene salaries are the main reason law tuition is so expensive. They are parasites that live off student loan cash while providing absolutely nothing of value in return. They are natural enemies of broke law students/graduates." ${ }^{69}$ Deans and administrators are treated even more harshly, and the writer emphasizes repeatedly the absolutely antagonistic relationship perceived to exist between administrators and students. After first opining that his or her law school dean was concerned about students failing out of law school solely because it would reduce the dean's comfortable lifestyle, the author relates the punch-in-the-gut disillusionment caused by the dean's brazen statements about succeeding even with low grades:

I had to meet with one of the deans before I dropped. She gave me the usual platitudes about perserverence [sic] and how I would succeed if I toughed it out.

67. For example, Nando-a prolific and author of one of the most well-known law school scamblogger, Third Tier Reality-states on his About Me page: "Furthermore, you will find it very difficult to find work as a non-lawyer, as your J.D. will make you overqualified for most non-law positions." Nando, BLOGGER, http://www.blogger.com/profile/ 06423524039657355134 (last visited Apr. 16, 2012); see also A Present from Esq. Never: Resume Advice for the J.D. Looking for a Non-Legal Position, EsQ. NEVER (July 5, 2010), http://esqnever.blogspot.com/2010/07/present-from-esq-never-resume-advice.html (recommending minimizing juris doctor as much as possible on non-legal job applications); Turde, Dumbass of Law Part 7: Final Thoughts, Do As I SAY, Not As I Do (Aug. 30, 2011, 10:17 AM), http://daisnaid9.blogspot.com/2011/08/dumbass-of-law-part-7-final-thoughts.html ("Law degrees on the other hand are completely $\mathrm{f}^{* *}$ king worthless. After spending $\$ 200,000$ on your degree ... you are left with nothing. Nobody will buy your fancy piece of paper, it's essentially a giant certificate that says: DUMBASS. Don't believe me? Put JD on your resume and apply to non-law jobs, see if anyone replies."); Rose, Esq., Reflections on my Job Search, ROSE COLORED GlasSES (Sept. 15, 2011, 3:40 PM), http://rose coloredglassesjd.blogspot.com/2011/09/reflections-on-my-job-search.html (noting the stigma attaching to JD degrees seeking non-legal jobs).

68. See Turde, supra note 67.

69. Id. (emphasis added). 
"Even if I'm in the bottom $25 \%$ of the class?" I asked?

"Yes," she replied. ...

This bothered me a great deal. . . . The Dean was flat-out lying. . . . "Dumbass, $F^{* *}$ khead, $S^{* *}$ tbrains. I'm gonna use your tuition money to get some landscaping work done on my yard." It takes a special brand of sociopath to ruin a young student's life for her own financial gain. ${ }^{70}$

What is apparently the most widely-read law school scamblog, anonymous blogger Nando's Third Tier Reality, is even more willing to step beyond traditional social taboos against overt scatological themes to deliver a color photo of human feces to introduce reviews and jeremiads against individual law schools and professors. ${ }^{71}$ The blog introduces itself in terms of muckraking and shared struggle. "If you graduated from law school . . . then contact me at nando9936@[] ... It is important that we continue to highlight this filthy industry."72

Counting over 400,000 visitors at the time of this writing, the blog viciously damns law school after law school through the continued theme that law schools are cheating their students. The cheating allegedly involves falsely claiming to provide a high-value educational product, that faculty and administrators are overpaid leeches that produce nothing of value, and that legal education amounts to a conspiracy to saddle law students with student loans for the continued enrichment of the legal education establishment. As one example states:

Conclusion: In the final analysis, __ Law Sewer's reputation is lower than fresh monkey feces. The school administrators and "professors" merely want to keep the gravy train rolling. MANY, if not most, of this dung pit's former students will never practice law. In contrast, the staff and faculty are paid up front, in full. The students, graduates and dropouts are stuck with NON-DISCHARGEABLE debt. Additionally, the school will argue that it is providing a "legal education" - not guaranteeing anyone a job. ${ }^{73}$

70. Turde, Dumbass of Law Part 6: A Miserable Semester, Do As I SAY, Nor AS I Do (Aug. 23, 2011, 8:57 AM), http://daisnaid9.blogspot.com/2011/08/dumbass-of-law-part6-miserable.html.

71. ThIRD TIER REALITY, supra note 51. Scatological equivalence with all things legal is one of the major cultural identifiers within the scamblogging community. Besides frequent references to "Third Tier Toilet" law schools ("TTT"), blog titles include SHIT LAW JOBS, http://www.shitlawjobs.com/ (last visited Apr. 16, 2012), FIRST TIER TOILET!, http://firsttiertoilet.blogspot.com/ (last visited Apr. 16, 2012), and THE PresTTTIGIOUS LEGAL PROFESSION, supra note 44.

72. Nando, THIRD TIER REALITY, http://thirdtierreality.blogspot.com (last visited Apr. 16, 2012) (quoting the "contributions" link in the right column).

73. Nando, Stink Pit Central: Fourth Tier Dung Pile Thomas M. Cooley Law School Sues Bloggers, THIRD TIER REALITY (July 18, 2011, 4:54 AM), http://thirdtierreality. blogspot.com/2011/07/stink-pit-central-fourth-tier-dung-pile.html. Astute readers who have made it this far and have bothered to read the footnotes will observe that I redacted the name of the school above despite that it appears in the citation. This was deliberate. I cannot help but note 
Still other law school scamblogs highlight the hopelessness and despair facing many law graduates as they encounter poor job prospects and ever-mounting, nondischargeable student debt. Although examples of this phenomenon are legion, the short-lived Sallie Mae's Bitch struck me most poignantly. The blog began in August 2010 with the author's initial attempt to get a handle on personal finances and debt service, followed immediately with a post regarding an upward adjustment to the author's monthly graduated repayment schedule. ${ }^{74}$

From there, the blog spirals downward through the realization that the author's parents (retired and on a fixed income) cosigned for some of the student loans and are now also liable for any default, through the decision to default on other loans not cosigned by the parents, followed by body-blow after body-blow in the form of revelations regarding the realities of nondischargeable debt, capitalization of interest, and loan servicing practices that would make the payday loan industry blush in embarrassment. ${ }^{75}$ The final post is tragic and heroic as the author emerges from the shock of her initial ordeal and displays personal development and strength in choosing to default on her loans rather than enter forbearance: ${ }^{76}$ "I'm enjoying my new sense of empowerment and mental freedom."”7

that the subject of this tirade had the chutzpah to sue one of its former students for defamation. See Jesse, supra note 13. In my opinion, having reviewed public accounts of the case, the defamation suit has no legal merit and, also in my opinion, bears the hallmarks of having been brought, at least in part, for the purpose of intimidating the school's critics. Consequently, having determined that, in my opinion, making negative comments about the subject may expose the commenter to the threat of bad-faith legal action for defamation, I have to stress here that all of the quoted statements are quoted as the opinion of a third party. I make no representation that the factual claims quoted above are true in any way, nor do I personally believe that the subject's reputation is literally related in any way to monkeys or their byproducts.

74. Sallie Mae's Bitch, SALlie MAE's BITCH (Aug. 24, 2010, 11:49 AM), http://almostdebtfree1.blogspot.com/2010/08/sallie-maes-bitch.html (blogging about an increase in monthly payments from $\$ 778.40 /$ month to $\$ 1967.91 /$ month).

75. See Sallie Mae The Billion Dollar Scammer! No Online Principal Only Payment Option!, Sallie MaE's BITCH (Sept. 19, 2010, 10:38 PM), http://almostdebtfreel. blogspot.com/2010_09_01_archive.html. Fortunately, it turned out that the author's parents were only co-signers on two of her loans. See Cosigner Nightmare and Plan C, SALLIE MAE'S BITCH (Aug. 26, 2010, 11:49 PM), http://almostdebtfreel.blogspot.com/2010/08/ cosignernightmare-and-plan-c.html. The author defaulted on all of her other loans and devoted herself to paying off the loans on which her parents were liable. Id.

76. Exercising My Right Not to Forbear, SALLIE MAE's BitCH (Nov. 18, 2010, 1:54 PM), http://almostdebtfree 1.blogspot.com/2010/11/i-hate-to-restate-obvious-but-i-have.html. The author apparently believes that loans in forbearance capitalize accrued interest, while loans in default do not. See id. I have no idea whether this is true or not.

77. Id. For similar thoughts, see generally DEBTOR's PRISON, http://mydebtorsprison.com/ (last visited Apr. 16, 2012) and Brutus, Esq., Gambling > Ph.D, CHILDREN OF DEBT (June 5, 2010, 7:46 AM), http://childrenofdebt.blogspot.com/ 2010/06/gambling-phd.html. 
Other blogs in this genre emphasize the "promised land" of escape from debt slavery to their student loans. Esq. Never, for instance, reports success on a fantasy held by many jobless lawyers. "In a nutshell, I can finally do what $I$ had endeavored to do from [the] inception of this blog: Declare 'Mission Accomplished.' Yes, slightly over a year and a half after graduating from law school, I now have a real, salaried, non-legal job in an industry in which I'm interested." ${ }^{88}$ Others, such as the now-defunct Esquire Painting, consider escape through fantasies of expatriation and suicide:

And so......what typically happens to me after thinking along these lines ... I end up realizing that it is far better to leave the USA and start over somewhere else where the student loan debt will not follow in the form of ruined credit, a future garnishment of social security[,] etc.

I mean, leaving the country is better than killing myself.

Right? ${ }^{79}$

Although the stories raised by these and similar law school scamblogs are heart-wrenching or crudely damning to the legal education infrastructure, many others raise more troubling narratives involving calls for the destruction of the enemy (in other words, us), calls for violence, and calls for rejection of and breaking from traditional legal culture. ${ }^{80}$ The introduction to Outside Lies Magic: A Law School Vendetta, for instance, calls for a traditional vendetta against the "Law School Industrial Complex":

This blog is about living the American Dream at the dawn of the new millennium! I am a nameless, mid-20s, bottom 150 Law School Graduate who finds himself marginally attached and awash in a sea of overeducated but underpaid, indentured peers who feel, and were, duped by the promise of a better life through debt and modern chemistry. Let's get to the point. The Law School Industrial Complex is a scam that has destroyed a generation out of greed. Vendettas were once legal and the pursuit of one was seen not only as moral, but necessary. This newly minted lawyer is going to continue the practice. DON'T GO TO LAW SCHOOL YOU MORONS! Ce qui suit est ce qui reste! ${ }^{81}$

78. Update: Mission Accomplished, EsQ. NeVER (Feb. 14, 2011, 7:00 AM), http://esqnever.blogspot.com/2011/02/update-mission-accomplished.html.

79. JDpainterguy, New Years Day and Thoughts of Suicide Over My Student Loan Debt, EsQuire PaINTING (Jan. 1, 2012), http://esquirepainting.blogspot.com/2012/01/howdefault-tacked-over-40-thousand.html.

80. The feces fascination demonstrated throughout the law school scamblog community is likely a manifestation of this last desire. By breaking strongly-held taboos of the dominant culture, such as by vividly displaying photos of feces and including scatological terms throughout the scamblog narratives, the bloggers identify themselves as members of the community and simultaneously manifest rejection of traditional communities for whom the scatological references are improper or obscene.

81. Demosthenes of America, No Surprise: Law Professors Have Ridiculously Cushy Jobs, OutSide Lies MaGiC: A LaW SchOOL VendetTa (Sept. 4, 2011, 8:13 AM), http://outsideliesmagic.blogspot.com/2011/09/surprise-law-professors-have.html (emphasis added). 
Outside Lies Magic expresses themes of angst, anger, betrayal, and social dissolution. The desire to do something, to lash out, to address the injustice is palpable throughout every post. In some cases, the scamblog shifts into completely violent imagery and is reminiscent of descriptions of the French Revolution. At one point, for example, Outside Lies Magic turns and attacks Paul Campos, the one faculty member who appears to be most sympathetic to the scambloggers, expressing a desire to become infected with a deadly disease just to be able to turn around and give it to Campos. ${ }^{82}$ In fairness, the author of this blog responded to a SSRN draft of this Article with a profanity-laced (albeit definitely not A-game material) personal attack on me in which he or she claimed that the blog did not actually represent how the author speaks in real life. ${ }^{83}$

Other similar blogs also call for a revolutionary break with traditional legal culture. But I Did Everything Right! rails extensively for destruction of the legal profession and legal academia:

Gimme a break! The "sense of exceptionalism," i.e. elitism, went out the window when $200+$ law schools opened up and started churning out attorneys like widgets. There is no exceptionalism, or "being special" in the law. I will not stop blogging until people are flatly unimpressed with my profession. It's not impressive. ${ }^{84}$

Another scamblogger is more directly threatening: "You hear me, you lying law school admins? Your muthaf***ing day is a-coming. Like in the movie SHAWSHANK REDEMPTION, that old pseudo-bible sayin' applies to YOU, law school admins: 'His judgment cometh and that right soon . . ,"," and "You hear me, law school $b^{* *}$ ches? Your day is coming, lying f**kers. ..."

At this point, the scamblog community has gone far beyond simple lack of decorum, and portions of it embrace the fantasy of violence against

82. Demosthenes of America, Oh Hi America, Glad You're Awake!!!, Outside LIES MAGic: A LAW SCHOOL VendeTta (Oct. 20, 2011, 10:28 PM), http://outsideliesmagic.blogspot.com/2011/10/oh-hi-america-glad-youre-awake.html. I cannot quote the actual text.

83. See Demosthenes of America, Here's Why Law Professors Are Evil \& Generational Fantasy Camp, supra note 5 ("Danny, do you really think this is my serious, actual person tone?'). It is an interesting question.

84. Angel, Are We Unprofessional? Do You Give a Shit?, BUt I DiD EVERYTHING RIGHT! (July 5, 2011, 8:01 PM), http://butidideverythingrightorsoithought.blogspot.com/ 2011/07/are-we-unprofessional-do-you-give-shit.html (emphasis added), .

85. HomelessLawyerPostingFromLibrary, US Senator Calls Out the Lying Law Schools and Their Fake Employment Stats, LaWYers Against The Law School Scam (Mar. 31, 2011, 5:27 PM), http://www.lawschoolscam.blogspot.com/2011/03/us-senatorcalls-out-lying-law-schools.html.

86. HomelessLawyerPostingFromLibrary, The Atlantic Asks About an "AntiCollege Backlash", Lawyers AGainst The LaW SChOOL SCAM (Mar. 31, 2011, 5:24 PM), http://www.lawschoolscam.blogspot.com/2011/03/atlantic-asks-about-anti-college.html. 
those perceived to have harmed, betrayed, or defrauded that community ${ }^{87}$ If this is the future, law faculty and administrators should be apprehensive.

\section{SCAMBLOGS AND THE RULE OF LAW}

So what does all of this mean? As noted, this Article does not purport to provide an exhaustive anthropological analysis of the legal scamblogger culture or community. Instead, I have pulled a handful of the myriad themes from a few of the large number of scamblogs that I believe are representative of the community. That description depicts a large community of disenchanted, disconnected, bitter, and angry individuals who share a common mythology regarding their beginnings. The community is cohesive and selfsustaining - as this Article goes to print, there is no indication that scamblogging is declining. The scamblogs and the community they represent are likely here to stay.

Likewise, I cannot show what kind of actual reach or impact the scambloggers are making. The scamblogging message appears to have deep penetration within the law student and recent graduate communities. Looking at the numbers of visitors these sites are getting, most are getting tens of thousands of hits and, in some cases, hundreds of thousands. Surveying my 1L Contracts class after giving the presentation on which this Article is based, almost all of them reported that they were very familiar with the scamblogs and news reports regarding the questionable return on investment of a law degree. Even after grades post for the first semester, the lack of attrition is stunning, particularly since I explain year after year in the strongest possible terms that maintaining a sub-3.0 GPA is a good indication that the student should cut his or her losses since the big law jobs are now almost certainly out of reach. Students may be consciously aware of the risks associated with investing in a legal education, but once they are in our doors they do not seem to adjust their behavior in response to that risk. ${ }^{88}$

87. I am not suggesting that the fantasy will necessarily become reality in terms of physical violence against faculty or administrators. As Professor Brian Kalt noted in reviewing a prior draft of this Article, the Internet is filled with over-the-top violent and extremist rhetoric. Rather, as discussed below, I am concerned with the developing narratives about what it means to go to law school and be a lawyer, and the ability of those narratives to redefine the commitment of new lawyers to legal institutions and the rule of law.

88. The fact that students are relatively well-informed and yet still keep coming is deeply troubling. In commenting on a draft of this Article, Professor Charles Ten Brink noted that the opening lecture I have given to every one of my $1 \mathrm{~L}$ classes for the last eight or nine years should result in $50 \%$ of my students deciding not to return after their first year. After opening the lecture with the statement that most of them should not be in law school, I walk them through the actual opportunity cost of attending three years of law school, the actual student debt they will face upon graduation, the actual low starting salaries they will receive if they are lucky enough to get jobs, and how difficult it will be to service their student debt on the average salary. They ignore me, just as they seem to have ignored the wamings of the 
Conversely, many colleagues at my own and at other institutions have expressed surprise when I have given examples of the degree of anger and bitterness toward law professors, deans, schools, the ABA, and other elements of the legal education infrastructure. Most of us by now know that something is wrong with legal education. And like Kafka's protagonists, we are trapped within a chaotic system over which we have no control. The rules of our system appear written by faceless bureaucrats at the ranking department of a mostly-failed news magazine, lenders willing to extend credit regardless of risk, and accreditation agencies like the ABA. Consequently, law faculty continue to do their jobs day in and day out while remaining only peripherally engaged in this critical matter.

My concern in all of this--beyond my sympathy for the life- and livelihood-destroying effects of crushing student debt and a miserable job market-is with what this new community represented in part by the scambloggers means for legal institutions, law, and the Rule of Law generally. Specifically, it does not matter anymore whether we believe that the scambloggers are just slackers who went to low-ranked schools and are now whining because they cannot get jobs. Given the number of my good students who have trouble finding any meaningful employment, I cannot believe that is the case. But even my beliefs do not matter now.

What matters is that the scamblogs exploit the information age opportunity to deconstruct and reconstruct cultural mythologies in a manner and at a rate unknown in human history. This new scamblogger legal culture has already identified with the narrative that they were cheated by a greedy cartel of banks, deans, admissions officers, professors, and law firms, that their lives have been destroyed, that their $20 \mathrm{~s}$ and $30 \mathrm{~s}$ and their hope for a middle-class living has been stolen, and that the "Law School Industrial Complex" is really just an instrument of oppression. ${ }^{89}$ Our students, or at least a significant subset of them, are participating in this narrative even while we try to explain the nice distinctions between risk of loss and rejection of nonconforming goods.

At this point, we are in a cultural crisis. This is not just a crisis in the sense that current law school models for delivering cost-effective legal education are badly flawed. Nor is it just a human crisis in the sense that many of our graduates now face a lifetime of crushing debt, bitterness, family instability, and other catastrophic consequences of the long-term slide in the legal services market. Instead, these narratives challenge us to recognize

scambloggers for at least the last two years. Or, as Professor Brian Kalt suggested in comments on this Article, they're overly optimistic that they will be part of the successful half of their graduating class.

89. See Demosthenes of America, OUtSide Lies MAGiC: A Law School VendetTA, http://outsideliesmagic.blogspot.com (last visited Apr. 16, 2012) (blog explanation). 
those factors and personalize them in a way that the normal bland academic discussions of "we should do something about that soon" have never done.

These new scamblogging narratives threaten the cultural myths of what it means to practice law, what it means to be a lawyer, and the relationship between the lawyer and the law. Such myths are powerful because they permit members of a culture that identifies with a particular mythos to (i) identify to themselves and to others as members of that culture; (ii) explain and exemplify the normative rules of behavior within that culture; (iii) justify the normative rules within that culture in a system of morality; and (iv) know what membership in the culture requires from those within it. ${ }^{90}$

The jury is still out on the staying power of the scamblogging movement, but the surprising explosion of these stories and their apparent saturation within law student and law graduate culture shows that they have the capacity to challenge deeply held traditional myths that we have used to justify going to law school, respecting lawyers and legal education, and the ethic of playing by the rules.

Consider what it means to have a generation of law students and law graduates who are convinced that they were defrauded by law schools into enrolling based on inflated statistics. That they were conned into taking out student loans on the basis of false predictions of their returns on their investment. That administrators are parasitic leaches whose only purpose is to keep students in law school until the students have been drained of every last dollar so that deans can play golf, have huge houses, nice cars, and all the other things that these students will never have. That law faculty are parasitic leeches who have amazingly cushy jobs, who hypocritically pontificated about practicing law while having no real or current experience, who cannot get the students jobs, and who do not work more than a couple hours a day. That when they graduate, only the best and brightest (for whom the rest of the class has been paying scholarships) ${ }^{91}$ get good jobs, while the rest of them are facing debt slavery and $\$ 12-\$ 30$ per hour contract attorney jobs or will even have to hide the J.D. on their resume to find a non-law job. Consider also what you would do if you learned through your law school experience the hard lesson that "playing by the rules" and "doing everything right" just gets you screwed, wastes your 20s and 30s, and destroys your prospects for happiness.

90. See BARNHIZER \& BARNHIZER, supra note 8, at 219-38.

91. As Professor Charles Ten Brink noted in reviewing an earlier draft of this paper, the idea that lower-ranked students are paying for higher-ranked students to attend law school is at least partly fallacious. There is no transfer from the bottom to top students-the top students receive a discount without which they would not be present at the school. While there is some marginal cost to having a $25 \%$ larger student body than would otherwise be present, that marginal cost is likely offset by the increased qualifications of the student body as a whole. Others disagree. This mathematical, financial, pedagogical, and philosophical question is, of course, beyond the scope of this Article. 
In what universe are the people who identify with this story going to support the system about which we have been telling them for three years of their lives? What loyalty will they have to the institution of the Rule of Law, when it is the instrumentalities of law that have driven their misery and oppression?

Lastly, as a practical matter, consider what it means to churn out 45,000 J.D.'s every year knowing that only 25,000 of them will get some sort of legal job, ${ }^{92}$ but that almost all of the remainder has the motive and the opportunity to use their legal skills to get back at the system that hurt them. As of this writing, seventy-three recent law school graduates have filed class action lawsuits against fifteen law schools (with more to come) alleging that the schools fraudulently reported inflated graduate employment rates and salaries. ${ }^{93}$

How long before some subset of the remainder begins working as legal "terrorists" to destroy the rest of the system from within by exploiting its own internal hypocrisies? If all you have is a law degree, a bar number, and a lot of time on your hands, very little effort would be required to generate a large number of legal actions or threatened legal actions against law schools, the ABA, Sallie Mae, and so on. Crackpot, meritless lawsuits are nothing new. What is new is that we now have a pool of 20,000 or more unemployed lawyers per year with both the cultural duty to strike back at institutions and individuals and the training to do so. Although some of the law school suits may be meritorious (and thus in the finest traditions of a Rule of Law system), in a system where hundreds of thousands of legally trained individuals have both the incentive and the legal tools to attempt to undermine the system from within, it is likely that the law school suits are merely the beginning of a train of legal actions against all of the institutions and individuals engaged in legal education.

The Rule of Law, as David Barnhizer and I have argued elsewhere, is a fragile social construct that depends upon the myths of the culture supposedly adhering to that concept to support it. ${ }^{94}$ Besides traditional notions of the Rule of Law as equality before the law, a government of laws and not of individual will, of basic procedural requirements such as notice of the law, neutrality, and generality, the Rule of Law is fundamentally a common good that requires everyone to exercise self-restraint in order to achieve the benefits of the common good. It is that self-restraint and belief in the law as an institution that, for instance, leads most taxpayers to file their taxes without

92. See Leichter, supra note 1.

93. See Martha Nell, 12 More Law Schools Sued over Reporting of Law Grad Employment and Salary Stats, ABAJourNAL.COM (Feb. 1, 2012, 4:39 PM), http://www.abajournal.com/news/article/12_more_law_schools_sued_in_consumerfraud_class_action_re_reported_law.

94. See BARNHIZER \& BARNHIZER, supra note 8, at 219-38. 
massive fraud, that leads customs clerks to do their jobs generally without too many bribes, that causes us to trust the courts to resolve our legal disputes. Without that ethic of self-restraint and shared sacrifice, the Rule of Law must collapse under an infinite number of corrupt or self-interested acts.

The rise of the community represented by the scamblogs threatens the Rule of Law because it challenges the traditional narratives that justify the shared sacrifice necessary to maintain the Rule of Law. What we are seeing with the scamblogging community is evidence of the development of a new cultural mythology. In that new narrative, a significant (and likely permanently oppressed "lumpen proletariat" stuck in dead-end, low-rent legal jobs) minority of lawyers buy into stories in which they are justified in believing that no one really plays by the rules because that is for suckers. The new narrative explains their personal misery in terms of betrayal and fraud by those who supposedly guard the Rule of Law. The new narrative delivers a new morality tale that suggests both revolution against the old order and that it is both morally right and necessary to screw over others before they screw over you. The Rule of Law cannot survive the active antagonism of the culture it relies upon for continued existence.

This Article does not suggest new solutions. We know the solutions are coming, that they will be radical, and that they will likely happen without the law schools being involved. Rather, this Article is a call to action on this critical problem of which the scamblogs are merely a symptom. Like the solutions that will eventually come if we do nothing, our actively sought solutions must be radical enough to fix the broken legal culture that is emerging. We have already likely lost much of this current crop of law students to the new narratives typified by the scamblogs. Once we lose the culture of the Rule of Law, it will not be back. 
